\title{
Parental Support in the Process of Choosing a First House (Case Study: Batak Families in Jakarta)
}

\section{Rossa Turpuk Gabe', Adinda Christina ${ }^{1}$, Angel Ecclesia Shiny', Joko Adianto ${ }^{1}$}

${ }^{1}$ Department of Architecture, Faculty of Engineering, Universitas Indonesia, Depok, Indonesia.

\author{
Article History \\ Received : 08 September 2021 \\ Accepted : 18 October 2021 \\ Published : 30 October 2021
}

\begin{abstract}
First-time home buyers have many considerations to choose their house after leaving the parental house. One of the determinant roles is culture. Culture influences activities, the meaning of home perspectives, and parental support system. Indonesia has a strong family culture, one of which is the Batak tribe. As one of the largest populations in Jakarta, this study focuses on the next-generation Batak process of selecting the first house. This study using case studies and qualitative research with in-depth interviews. We found that culture influenced the moving stage and parental support role. The parents play two essential parts: they are mindset formers as well as providers of financial support. Although the housing preferences tend to be similar to the firsttime homebuyers in urban areas, culture influences the spatial arrangement process. The finding can contribute to how parental support affects the next generation of migrants while adapts to the housing market.
\end{abstract}

Keywords: Batak family; culture; housing preferences; parental support

\section{Introduction}

When a new family is investing in their first house, whether they are renting or buying, the choice of a house is a big decision that must consider any options carefully. In general, consumers will go through three stages in terms of choosing a house: the decision to move, the choice of destination, and the house selection (Brown \& Moore, 1970).

As the decision to moving stage, mobility and migration has become an inherent element of Indonesian culture, known as merantau. Merantau is a long tradition from Sumatra (western Indonesia) when someone leaves their hometown (kampung halaman) to pursuit experience or to earn sustenance (Salazar, 2016). The ethnic group migration practices determine the chance of individuals to migrate

Correspondence:Adinda Christina Department of Architecture, Faculty of Engineering, Universitas Indonesia, Depok, Indonesia

E-mail: adinda.christina71@ui.ac.id
(Auwalin, 2020). One of the ethnic groups who carry out the tradition of wandering is the Batak tribe from Sumatra, as the thirdlargest population in Indonesia with 8.5 million inhabitants (BPS, 2010). Over time, this mobility process has evolved from temporary: move to return home, to become a permanent migrant. For Batak people, tradition is essential, so that even though they are far from their hometown, they still carry their values and culture (Bruner, 1972).

Started from the 1990s, many young families who had been born and raised in the land of Batak, North Sumatra, moved to and married in Jakarta, the capital city of Indonesia. According to Reid (2011), the migration of people from North Sumatra to Jakarta continued to advance rapidly in the years between 1970 and 1990 . Until 2010, according to the data retrieved from the Central Bureau of Statistics (BPS, 2010), the proportion of Jakarta's population that was of Batak origin was the fifth largest, with a total of 326,645 people. Moreover, as the amount of vacant land in Jakarta diminishes over time, new families are increasingly faced with the 
necessity of considering stock housing market in Jakarta where houses are already built or perhaps if they can be flexible, properties that are not located within Jakarta itself but rather in its satellite cities: Bogor, Depok, Tangerang, and Bekasi. Therefore, the information is important in the choice of the destination.

First-time buyers tend to search for as much information as possible from various sources before making a decision. The choices develop through a selection process based on their preferences and conditions. According to Priemus (1984), and Gibler and Nelson (2003), several factors influence housing choice, including preferences, reference groups, information sources, government regulations, availability, the consumer's financial situation, and so on. One of the most interesting factors is preferences because these are considered something personal, depending on each consumer's tastes or desires, and influenced by the consumer's experiences and the context. Significantly, housing preference is influenced by elements of culture (Jabareen, 2005).

Jakarta's population has a mix of tribal origins, languages, and nationalities, forcing people from diverse cultures to live alongside each other. As more and more Batak families relocate to Jakarta and raise the next generation in the city over time, these families are likely to become less interested in preserving Batak traditions because they experienced acculturation or even assimilation into the environment where they were born and raised. The value shifting can pose new challenges in housing supply as a representation of consumer preference in the future (Gibler \& Nelson, 2003).

The value changing or the acculturation as the impact of the adaptation process in the current environment also affect the moving process after marriage, except the parental support. The traditions related to parents support their part of parents though it is not an obligation. Parental support is known as the manjae tradition in the Batak tribe. Manjae means separate, the transition to leave their parental house experienced by the young adults when they get married as the symbol of independence and maturity (Vergouwen, 2004). The influence of broad tradition along with the specific tradition of parental support for the children when buying or renting house process shows that a new family's tribe and parents play a pivotal role in the decision-making process in choosing a house.

In another study from different ethnic and geographical contexts, parental support also has various meanings and reasons (Druta \& Ronald, 2017; Holdsworth, 2004; Barban \& Zuanna, 2010; Yu, 2021). The influence of cultural elements on housing preference and choice will differ across geographic contexts and will continue to evolve depending on how a group responds to or adapts to a new place. How does the Batak tribe, as the fifth largest ethnic group in Indonesia, adapt to the Jakarta, Bogor, Depok, Tangerang, and Bekasi housing market? How do Batak new families choose their first houses, and how do parents intervene? What is the form of support from Batak parents?

This paper aims to discover the cultural influence in selecting a house and the parental support traditions of first-time home buyers Batak family in Jakarta. In the literature review section, this paper will explore the house decision-making process, the understanding of housing preferences, the cultural perspective integrated with parental support. The method section discusses the research targets and methods. The discussion section examining the housing decision-making process and the parental support types refer to the qualitative analysis followed by an exploration of the findings with previous concepts or research from various socio-cultural contexts. In the end, it concludes the role and the influence of the Batak culture on the behavior of the young family to provide and choose their first house in the high-density urban areas.

\section{Literature Review}

\section{Housing Preferences and Housing Choices}

Housing preferences and housing choices are two different yet related terms. Housing preferences are a list of attributes that the consumers are seeking in the house they plan to buy or rent. Housing choice, on the other hand, is the outcome of the decision-making process (Gibler \& Nelson, 2003). In the process itself, in broader terms, consumers can be described as going through three major steps, namely, an 
information search, evaluation of alternatives, and decision rules (Gibler \& Nelson, 2003).

After deciding to buy or rent, a consumer's family determines their preferred location, budget, and timeframe. To narrow down the searching process, the family will have to specify their preferences. After identifying their needs and wants, the family can start the information search process. The information resources become very important in the housing choice process after leaving the parent's house (Smith, Mulder, \& Hooimeijer, 2007). According to Gibler and Nelson (2003), there are two types of information based on the resource: internal and external. Internal information is obtained from the consumer experiences during the interval between their last and present purchase, as indicated by the consumer satisfaction level with previous purchases. External information is obtained from friends, family, real estate agents, or media. For the family consumer, external information becomes pivotal due to their lack of experience in buying or renting housing (Diaz \& Hansz, 1997).

Many factors should be taken into consideration by the consumers, not only budget, timeframe, and preferences, but also government regulations, housing availability, and internal and external determinants, if the consumer family is to make a sound decision that will benefit the family's life in the long term (Gibler and Nelson, 2003). Internal and external determinants influence the decision-making process as well as the family's preferences. Internal determinants consist of motivations, attitudes, perceptions, personality and selfconcept, and lifestyle. These determinants are formed inside by the individual based on his or her mental and emotional characteristics (Gibler \& Nelson, 2003). External determinants consist of culture, social class, reference groups, and family. Both internal and external determinants potentially contribute to forming the consumer's preferences and behavior in purchasing houses.

At the end of the long process of identifying needs and preferences and gathering information, the family will have to choose the housing option that is closest to their ideal standards: a quantity and quality reference constructed about the housing situation based on their needs, experiences, and aspirations (Galster, 1987). Family's ideal standards for a house, or what we can now call the family's preferences, make the information search process more manageable. In reality, the outcome of the choosing process, namely the housing choice, does not always meet all of the family's housing preferences as many other factors need to be considered simultaneously throughout the process. The consideration process necessarily leads to compromises. Generally, compromises must be made by the consumer concerning three key factors: the right price, the right location, and the right size (Cornett, 2018). A single house will rarely be ideal in terms of all three factors.

The ideality of a house is divided into two: subjectively and objectively (Priemus, 1984). Subjectively, a house is considered ideal for a consumer when it meets the consumer's preferences, ignoring availability and budget factors. Objectively, a house is considered ideal for a consumer if it accommodates the main functions of a house according to experts, whose arguments involve economic considerations, planning, and other factors.

\section{First Move: Determinant of Culture Family}

Move from parents' house and start their own family is part of a transition to adulthood (Clapham, 2005). This transition stage is influenced by geographical context and culture as a determinant of community beliefs, values, customs, shared meanings, rules, rituals, norms, traditions (Solomon, 1996). As a representative of racial, ethnic, and religious groups (Assael, 1992), culture creates standards, needs, and behavior, starting in the family.

Family culture has influenced housing needs and housing preferences. According to Clapham (2005), the young family's view about the house will be significantly influenced by their parent's view of the ideal conditions of a house. The parent's housing values will manifest in their child's choice in the phase of leaving the parent's house and choosing their first house. The final decision of their house and how young families live will represent their experiences and events during their stay at the parents' house (Mulder \& Lauster, 2010; Clapham, 2005). That event based on the family life cycle theory described by Jansen, Coolen, and Goetgeluk (2011), consisting of nuclear family formation (cohabitation, marriage), 
expansion (birth of children), contraction (children leaving the house), and dissolution (divorce or death of a spouse), all of which alter the size and composition of the family. The discussion about the family becomes the framework of behavioral norms between parents and children (Clapham, 2005). Since Indonesia is one of the most densely populated and culturally diverse countries, the traditional system of each ethnic group reflects the ethnic and linguistic composition of the entire territory (Hugo et al, 1987).

\section{Intergenerational Support For Choosing The First House}

Parents' beliefs in supporting young families to get a house varies, depending on the family culture. The type of support may vary among various forms, including help with the information search, advice, financial support, buying assistance, building assistance, property donation, and others (Druta \& Ronald, 2017). Tangible support (financial assistance, buying assistance, and property donation) must only be given if doing so will not harm the parents' financial situation. The source of these tangible supports also varies, as they can come from the parents' savings, retirement houses, family inheritance, or family real estate (Druta \& Ronald 2017). In the UK context, gifts and support will create a debt-relationship between the parents and their adult children. This happens because there is a moral burden and debt of gratitude on the part of the receiver as a side effect of receiving the support (Godbout \& Caille, 1998; Druta \& Ronald, 2017). This debtrelationship can indirectly help to maintain the relationship between parents and their adult children, such as, for example, when adult children visit their parents more regularly than they would have without the debt-relationship, or when they make a special effort to visit them on holidays because they feel that they owe it to the parents. Another consideration is that, when parents gift their children with homeownership, the family wealth stays in the family (Weiner, 1992; Sjørslev, 2012; Druta \& Ronald, 2017).

Druta and Ronald (2017) group the types of financial partnerships between family members into four categories. First are intrafamily financial partnerships where parents give financial support in the form of payment loans or when siblings make a joint investment in a house. This kind of support is the strongest debt relationship, considering that the support given is in the form of loans. Second is the parental contribution, where the parents contribute not only in the form of funding but also in helping with the information to search and provide guidance and advice in the housing process, from choosing to building and even to decorating. This type of support is given by parents who desire that their children, at the very least, will live on the same level as they are from the social class aspect. On the other hand, excessive financial support can potentially hurt the children's self-esteem as it highlights the fact that they are not able to build their own house. The third is imbalanced support, which requires more re-negotiations than the other three supports. Imbalanced support causes unending reciprocity as the result of the dependency between parents and children. It also makes both parents and children unable to establish complete authority over their own nuclear families. Fourth is (in advance) inheritance. In the housing ownership context, in advance inheritance comes in the form of property that is inherited between generations. However, such inheritance does come with the potential to cause a problematic debt relationship. For example, a husband may not feel that he owns his own house if it was inherited from his wife's family. In this case, the husband may feel guilty that he is unable to provide a house for his family.

According to BPS (2010), ethnic groups are identified in the location or area of residence of a group of ethnic groups or regions that indicate the origin of the tribe. Indonesian culture has values with a strong influence, especially in family culture. Extended family members are a pivotal part of one's identity and are a source of moral and material supports. For the Batak tribe, one of the preserved traditions is family support, known as the Manjae tradition. Manjae is the Batak tradition for newlyweds or young families who still live in the husband's parents' home that are supported by the husband's parents in their endeavor to move to their own house, either bought or rented. Unless the newly married son is the only son or the youngest son, he and his wife (his new family) cannot stay in his parent's house for long. 


\section{Methodology}

Jansen, Coolen, and Goetgeluk (2011) have proposed the seven steps in the process of choosing a house, while Gibler and Nelson (2003) suggested three steps. In general, the process can be simplified to these steps: 1) specifying housing preferences, 2) understanding budget and urgency, 3) searching for information based on the preferences and other factors, 4) evaluating gathered information, and 5) choosing the right house. Housing preferences are influenced by internal and external determinants. In the external determinants, there are several intrafamily interventions by the parents, namely financial support, advice, and guidance. The consideration of the parents as part of their children's new family highly influences their children's preferences. Therefore, this study examines the Batak family process in choosing their first house and how cultural intervention plays its role.

This study employs a case study research method with a quantitative and qualitative approach. Data collection is focused on Jakarta as the capital city of Indonesia or one of its satellite cities, Bodetabek district (Bogor, Depok, Tangerang, or Bekasi district). Most of the developed land in the Bodetabek district is being used as residential belts. According to Coldwell Banker Commercial (2017), the total population of Bodetabek Area by age group is $45.4 \%$ Productive Working age (aged 15 to 64). This study aims to identify first-time home buyers' Batak family preferences, the manjae tradition practice, the kinds of support that Batak parents give to their children when the children are choosing their first house, and the final decision on housing choice.

The respondents' criteria are coming from a Batak tribe, married less than five years of age, born and lived in Jakarta with the ownership status or rented house not more than fifteen years and living separately from their parents. The selection of the Jakarta area as the birthplace is to find out whether there is an erosion of the interest of the younger generation towards the tribal traditions that affect their preferences based on traditional needs. The questionnaires were distributed and acquired by 100 eligible respondents. The questionnaire consists of 34 questions about their demographic situation, the considerations when looking for their first house, both tangible and intangible information sources they used; how often traditional activities are followed, home preferences and choices, and the support provided by their parents when they were choosing their first house. The questionnaire was compiled using a google form and distributed through social media platforms.

In-depth interviews were conducted with three randomly chosen Batak families with different types of housing ownership, monthly income levels, and family compositions. The in-depth interviews are intended to clarify the process that each Batak family went through when choosing their first house, and the forms that their parents' intervention took throughout the process. The interviews also intended to determine the correlation between parental support throughout the choosing process.

\section{Result}

Based on our data, $64.28 \%$ of respondents bought their first house, $15.18 \%$ rented, $14.28 \%$ lived in a house that was owned by the respondents' parents, and the remaining $6.25 \%$ were categorized as others as their first homes were in office facilities or relatives' houses. The reasons behind the respondents' decisions to start living separately from their parents also varied: $67.86 \%$ stated that they had moved out of their parent's house because they had gotten married, $34.82 \%$ stated that it was because of the need for independence, $14.28 \%$ stated because they had become financially established, while the other $8.92 \%$ stated that it was due to the presence of new family members.

In the process of choosing a house, many factors need to be considered frequently at the same time. Based on our data, almost every respondent considered location to be more important than other factors such as price and size. Twenty-five respondents wanted a house near their workplace, 39 wanted to be close to their parents' or families' houses, 51 wanted to be near their social facilities (school, house of worship, mall, market), 20 wanted to be near public transportation, and the other 11 had other criteria, such as environment, easy access to downtown, price, and architecture style or obtained their house through their employer's 
housing program or as a gift from their parents. However, these figures are somewhat vague, as some respondents chose more than one factor.

Regarding the information sources that the respondents used to look for their first house, nine respondents had searched for information from housing exhibitions, 14 had gathered information from their core family, nine from real estate agents, 32 from their relatives, and 16 from printed or online media, while the other 32 had conducted independent searches through surveys or obtained their house through their employer's housing program or as a gift from their parents.

According to our research, parental support comes in many forms, including considerations, financial support, or even a house or empty land. 63 respondents' parents had contributed considerations, 16 in the form of financial support, 12 in the form of a house or land, 9 in the form of furniture or appliances. In addition, 3 respondents' parents had given moral support and prayers, 1 had helped with the moving process, 1 had designed the house, and 14 had not given any support.

Based on an in-depth interview of the three Batak families, there is similar behavior in looking for a house which is suitable with phases described by Jansen et al (2011). The respondents experience the stages of problem-solving, even though not all of these stages were followed through. In the selection process, there were compromises in various aspects that failed the achieving of their ideal preferences. Financial capacity and housing stock are determinants when seeking to buying or renting a house. After deciding to move, some families do the manjae and there are people who don't. Although the practice of the Manjae ceremony is different, there is parental support as a part of the family culture. This support was found to be depending on the economic capacity of the parents, regardless of the young family's financial capacity.
Figure 1. Culture in the Transition to Leave the Parental Home Diagram

Source: Author

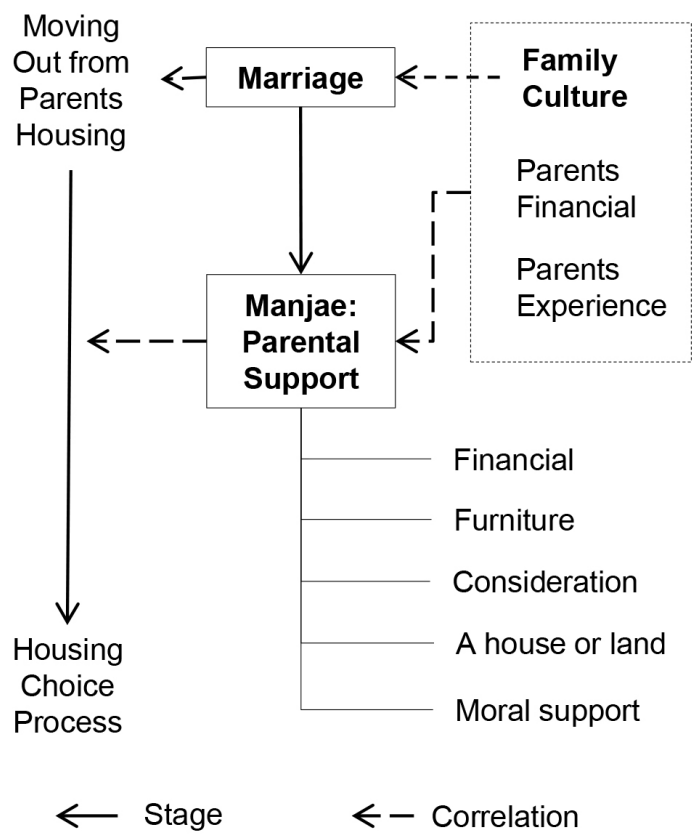

\section{Discussion}

\section{Batak Families' First House}

Preference and Housing Choice of Batak Family

In the family transition, there is a strong relationship between marriage and investing in their first house, particularly homeownership as a secure investment, stability, and create a propensity (Holland, 2012; Mulder, 2013). Marriage as a determinant of migration has shown a strong relationship with cultural values regarding maturity. This is shown by the findings that $67 \%$ of respondents leaving their parents' house and choosing to buy or rent in the same year of their marriage or less than two years. The process of young adults who decide to be independent and leaving their parents' home is a transition that requires a strong consciousness of the culture (Mackie, 2016). Since Indonesia is one of the most densely populated and culturally diverse countries, the traditional system of each ethnic group reflects the ethnic and linguistic composition of the entire territory (Hugo et al, 1987). In Indonesia, the norm of the marriage tradition can persist even when society is in the process of rapid socio-economic development (Buttenheim \& Nobles, 2009). That belief is carried along by the migrants to their new places and passed 
down to their children and becomes the fundamental reason to move.

In the choice of destination stage, Batak people in this area are forced to choose readyto-occupy houses rather than building their residence independently. It is influenced by the fact that it is hard to find any vacant land in Jakarta, Bogor, Depok, Tangerang, or Bekasi. Therefore, one of our most tangible findings is that first-time homebuyers or renters rely on external information sources when searching for available houses. The first-time buyers and renters tend to rely more on external information because they do not have any internal information due to their lack of previous experience in buying or renting. The availability and the characteristics of the intended location influence the housing choice and correspond to Myers et al (2005) that these conditions affect the housing preferences.

Housing preference is formed based on family culture and assimilated with the current residential context as a response to adapt to the available choices. This is shown by the majority of Batak families whose final decision to make their choices is based on the location preferences within proximity to the facilities. This preference is similar to the findings of millennial first-time homebuyers in Jakarta (Mulyano, Rahadi, \& Amaliah, 2020), first-time homebuyers in Kuala Lumpur (Tan, 2012), and young adults in the UK (Blumenberg et al, 2019). That is also a crucial factor for families with retirement intentions (Zahirovic and Gibler, 2019). The limitations of the market and economic capabilities have driven the family consumer to make a compromise eventually. This finding shows that the housing preferences and final choices of Batak families tend to be similar to the housing preferences of first-time homebuyers in urban areas.

\section{Batak Tradition and Housing Arrangement}

For members of the Batak tribe, a house is more than just a shelter, a place to do domestic and other daily activities, or an investment; it is considered sacred. A house is believed to bring blessings to the people who live in it. Batak people believe that a house is a pangalapan sangap (pride conveyor) and a pangalapan tua (happiness conveyor), and they accordingly take extra care in building their houses. Traditionally, Batak houses in North Sumatra were built to accommodate many households and guests so that the homeowners could host traditional events. Generally, there are two major kinds of events for which Batak people in North Sumatra host guests in their houses. Some involve fewer guests and others welcome many. Examples of smaller events or perhaps even private events are mambosuri (the celebration of the seventh month of pregnancy), birth celebrations, and many others. Bigger events with many guests include engagements, weddings, deaths, and other events. In urban life, in places such as Jakarta, Batak people no longer hold most of these bigger events in their houses. Nowadays, there are many halls throughout the city that they can rent for the celebration. The Batak tribe is wellknown for its long-lasting parties. They spend, for example, two hours on the Catholic portion of a marriage ceremony and an additional seven to eight hours on the traditional portion. A traditional wedding ceremony involves hundreds or possibly thousands of guests.

Furthermore, there is also a long tradition that Batak migrants hold arisan (monthly gatherings). Each clan has its own arisan event. Commonly a family will attend at least two monthly arisan, either from the husband and the wife's clan. The arisan tradition aims to maintain the relationships between every member of the family clan. The number of people participating varies among the districts. Willingness to join the young family gathering is determined by how the parents are involved.

Yes, I participate in arisan activities (traditional social gatherings), so I prefer to have sufficient space for these activities (Respondent 1)

Although there are compromises in the choice of housing due to financial capacity, there is a desire to accommodate social activities in the arrangement process of the space. Influenced by strong family bonds, spaces are endeavored to meet the needs of extended family or relatives, such as adequate space for social gatherings and additional rooms.

I want to have two outside bathrooms. My parent suggests having one squat toilet and one sitting toilet so that the elderlies can use it. 
For me, I want no barrier between the living room and family rooms so that the room can hold arisan events (traditional social gatherings). I also want an additional bedroom on the first floor for parents or family if they want to stay overnight. (Respondent 2)

Culture indirectly determines the space organization process through the activity. According to Rapoport (2000), activity is the most specific cultural expression. Thus, the utilization of space in residence can reflect standards and norms. The existence of these spaces has shown that for the generations who were born and living in Jakarta, social activities among the Batak family are still solid and maintained, especially for clan members. Therefore, the findings show that tradition is one of the considerations in fulfilling housing needs for Batak first-time home buyers.

Figure 2. Culture in the First Time Home-Buyer Preference Diagram

Source: Author

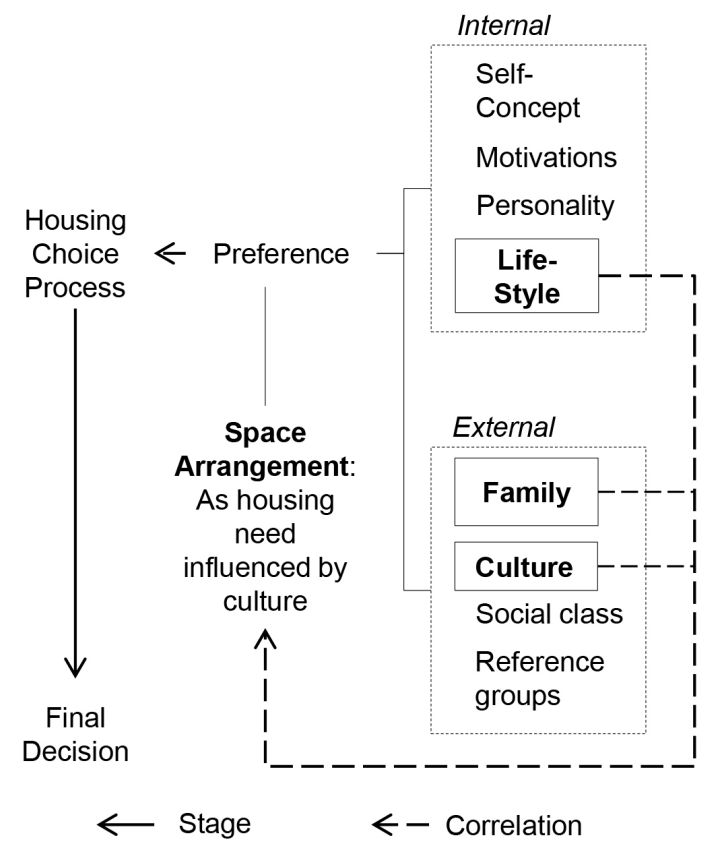

\section{Parental Support in Batak Families' Choice of a First House}

According to Druta and Ronald (2017) in the UK context, supporting a child's first home buying experience is considered an achievement for parents, as long as they can achieve it without risking their financial situation. This support is also referred to as a 'gift' and is a form of giving bigger responsibilities to one's adult children when they are unable to take them on alone. In the study conducted in Great Britain, parental support is a response to the absence of housing policies support. Whereas in Spain, parental support is something to ought, so that the welfare of young families can be achieved (Holdsworth, 2004). For ethnic Italian migrants, this is a strategy to live close together (Barban \& Zuanna, 2010). It is also different from the Chinese family's perspective, where parental support is the only way for young families to reach the housing market (Yu, 2021).

In the Batak tribe, there is a tradition that newlywed couples live in the husband's family's house for a while. However, when that time is over, they have to follow the manjae tradition. Traditionally, manjae takes place when a man begins to live independently with his new family, separate from his parents. Manjae is something to be proud of when it is achieved (Simanjuntak, 2009). When a man leaves his parents' house with his wife, he receives support from his parents. This support can come in a variety of forms depending on his parents' capability but may include funds, a down payment, land, a house, and so on. The wife's parents often provide support as well, but their support is more often in the form of complementary goods such as furniture and household appliances (Vergouwen, 2004). Again, however, whether a young family receives this support depends on their parents' capability, especially their financial situation.

In the Batak tribe specifically, choosing one's first house requires extra attention as the house is believed to be sacred. This explains why most of the respondents' parents supported them in the form of consideration or advice. Since the Batak tribe practices manjae as a tradition, financial support to organize this is the second most frequently given type of parental support. However, parental support in the form of consideration is also essential for a family from the Batak tribe. Batak parents are only involved in the choosing process of a new Batak family's first house. Their level of involvement differs among families. For example, parents of respondent 1 suggested after giving financial support that it would be best if the respondent's family could find a house near the parents' house. It turned out that the respondent and her husband could not find a suitable house near their parents' house, as the closest suitable house was 40 minutes 
away by car. They felt it was important to move to a bigger house, even though they eventually bought their second house near their first house because they still could not afford any house near their parents' house.

As suggested by the findings above, the two most common forms of parental support given to new Batak families in the process of choosing their first house are consideration and financial support. Twelve respondents had received property as a form of parental support, ranging from a house to a piece of land. Property, however, cannot be considered a form of financial support because the heavy debt of gratitude is different, even though it is insignificant. Parental financial support is defined as gifts or loans of money, whereas property as parental support can come in the form of a house or empty land.

The incurred debt of gratitude when a young family receives financial support is more likely to be 'paid', whereas this is not the case when the property is given, considering the greater quantity of a gift of property. Moreover, after giving financial support, parents may also give intangible support, such as consideration, advice, or even preferences. To 'pay' their debt of gratitude, adult children may try to fulfill their parents' 'requests' that constitute this intangible support, even though the parents tend not to impose their will.

My parents said not to force ourselves in choosing the residence, just adjusted to the financial condition, but if possible to choose a house around East Jakarta, to be near with the family. (Respondent 1)

As for parental support given in the form of a house or land, it might stop at giving this property, but the heavy debt of gratitude will possibly stay with their children and become an infinite debt of gratitude. It would be considered inappropriate in such a case for the children not to fulfill future requests from their parents. For example, if a family member from the children's hometown came to the city where the children live, and the children's parents invited the family member to stay at the children's house, it would be inappropriate to refuse. They would have to host the family member regardless of the effort or trouble involved. Moreover, a gift of property may cause the children to think that they are incapable of purchasing their dwelling because gifts in the form of a house or land are no different from an (advance) inheritance. According to Druta and Ronald (2017), parental support creates a debt relationship for children even from a parent's perspective: the decision to support is driven by their experience when moving from their parent's home. Both because of difficult experiences when moving out (Holdsworth, 2004) or based on the experiences when getting support from their parents (Albertini et al, 2018).

Especially for a rented house, tangible parental support does not always lead to intangible support. For example, when parents give financial support to their child to help him buy his family's first house, the child does not necessarily have to fulfill any preference suggestions from his parents; simply considering them will be sufficient. This was the case for one of three respondents that we interviewed:

\section{My parents suggested a location to rent, but I wasn't comfortable with the environment. Finally, I chose this place here, even though my parents didn't like this location and they suggested moving to another house immediately. (Respondent 3)}

The respondent and her family received parental support in the form of rental payments. This finding is contrary to the study conducted in the European context. Parents, especially homeowners, tend to be reluctant to provide their children's family rental payments because of the consideration that financial support is better allocated to housing deposits (Heath \& Calvert, 2013).

Later, when searching for another available rental house, the respondent's father-in-law helped with the search and suggested a rental house near his own house. Nevertheless, the respondent and her husband decided to ignore this suggestion as the house did not meet their preferences. According to Holdsworth (2005), although the child's family receives parental support continually, this causes many conflicts with their parents. In this study, the disagreement occurs at the decision of the renting house location. With further questions and answers, we concluded that, especially for rental houses, a family prefers to choose the house that will provide them with enough 
comfort until they are capable to have their own home.

The advice is the dominant contribution from parental support when a Batak family is involved in the home buying process for the first time. A request to be close to the parent's house and the suggestion on the arrangement of residence space are a majority type of advice. This finding represents that the size and form of parental assistance did not affect the final decision on the housing choice as the young families will eventually determine it themselves.

\section{Conclusion}

There are two inseparable concepts involved in choosing a house, namely, housing preferences and housing choices. Internal and external determinants influence housing preferences; one of the external determinants is family, specifically, the new family's parents. Housing preferences can potentially lead to a housing choice, but will not always be based on cultural background and family traditions do not significantly influence the housing decisionmaking process taken by the Batak family. The preferences of Batak families tend to be similar to the general housing preferences of first-time house buyers in urban areas. This is conflicted with the process of organizing the space of the house. Traditional activities are found as a determinant consideration for the Batak family, especially in the common room area.

Parental support received by the Batak family when choosing their first house will vary depending on the parent's capabilities and not on the child's. We found that consideration is the most common type of parental support, while financial support takes second place. Although parents may provide only small deliberation, the children are found to still considering it, as the members of the Batak tribe view the houses to have an important meaning and due to their lack of experience in selecting a house. However, we found that parental support is given only during the choosing process. After the children have made the final decision, parents do not intervene in the household management.

This research attempted to provide another view of the housing market from a cultural perspective for the next generation of immigrants. This study is also beneficial as it provides different approaches for the architect to design a convenient house that can support the traditional activity. However, the correlation of parents' demographic and the background of Batak family who moves for the first time from their home town is the limitation of this study. The spatial adjustment strategies to support the cultural activities can be the topic of further study.

\section{Acknowledgement}

The authors would like to express gratitude to the Department of Architecture, Faculty of Engineering Universitas Indonesia (FTUI) for their support in this research.

\section{References}

Albertini, M., Tosi, M., \& Kohli, M. (2017). Parents' housing careers and support for adult children across Europe. Housing Studies, https://doi.org/10.1080/02673037 .2017 .1363875

Assael, H. (1992). Consumer Behaviour \& Marketing Action. Boston, MA: PWS-KENT.

Auwalin, I. (2020). Ethnic identity and internal migration decision in Indonesia. Journal of Ethnic and Migration Studies, 46(13): 2841-2861. https://doi.org/10.1080/13691 83X.2018.1561252

BPS. (2010). Kewarganegaraan, Suku Bangsa, Agama, dan Bahasa Sehari-hari Penduduk Indonesia. Hasil Sensus Penduduk 2010 (p. 36). Retrieved April 7, 2019, from https://sp2010.bps.go.id/files/ebook/ kewarganegaraan $\% 20$ penduduk $\% 20$ indonesia/index.html

Barban, N. \& Dalla-Zuanna, G. (2010). A Portrait of Immigrant Children's Housing Experiences in Italy. Housing Studies, 25(4): https://doi.org/55958410.1080/02673031003712053

Blumenberg, E., Brown, A., Ralph, K., Taylor, B., \& Voulgaris, C. (2019). A Resurgence in Urban Living? Trends in Residential Location Patterns of Young and Older Adults Since 2000. Urban Geography, 40(9): 1-23. https://doi.org/10.1080/02723 638.2019.1597594.

Brown, L. A., \& Moore, E. G. (1970). The IntraUrban Migration Process: a Perspective, Geografiska Annaler: Series B. Human 
Geography, 52(1): 1-13. https://doi.org/10 .1080/04353684.1970.11879340

Bruner E M. (1972). Batak Ethnic Associations in Three Indonesian Cities, Southwestern. Journal of Anthropology, 28(3): 207-229. The University of Chicago Press

Buttenheim, A. M., \& Nobles, J. (2009). Ethnic diversity, traditional norms, and marriage behavior in Indonesia, Population Studies, 63(3):277-294. https://doi. org/10.1080/00324720903137224

Clapham, D. (2005). The Meaning of Housing: A Pathways Approach. Bristol. UK: Policy Press.

Coldwell Banker Commercial Indonesia. (2017). Property Market Overview in BODETABEK Area. Retrieved August 20, 2019, form http://www.cbcindonesia.com/ research/19/property-market-overview-inbodetabek-area

Cornett, B. (2018). Common Compromises When Shopping for a House. Retrieved from http://www.homebuyinginstitute. $\mathrm{com} / \mathrm{mortgage/compromises-when-}$ shopping-168/

Diaz, J. \& Hansz, J.A. (1997). How valuers use the value opinion of others? Journal of Property Valuation and Investment, 15(3): 256-260. https://doi. org/10.1108/14635789710184970.

Druta, O., \& Ronald, R. (2017). Young Adults' Pathways into Homeownership and the Negotiation of Intra-Family Support: A Home, the Ideal Gift. Sociology, 51(4): 783-799. https://doi. org/10.1177/0038038516629900

Gibler, K. M., \& Nelson, S. L. (2003). Consumer Behavior Applications to Real Estate Education. Journal of Real Estate Practice and Education, 6(1): 63-84

Holdsworth C. (2004). Family Support During the Transition Out of the Parental Home in Britain, Spain, and Norway. Sociology, 38(5): 909-926. https://doi. org/10.1177/0038038504047179

Holdsworth, C. (2005). 'When Are The Children Going To Leave Home!': Family Culture And Delayed Transitions In Spain. European Societies, 7(4): 547-566. https:// doi.org/10.1080/14616690500342568

Holland, J. A. (2012). Home and where the heart is: Marriage timing and joint home purchase. European Journal of Population, 28(1): 65-89. https://doi.org/10.1007/ s10680-011-9242-1

Galster, C.C. (1987). Identifying the correlates of dwelling satisfaction: An empirical critique. Environment And Behaviour, 13(6): 735-758.

Godbout, J. T., \& Caille, A. (1998). The World of the Gift. Canada: McGill-Queen's University Press

Graeme, J. H., Terence, H. H., Valerie, J. H., \& Gavin, J. (1987). The demographic dimension in Indonesian development. New York, Oxford: Oxford University Press Heath, S., \& Calvert, E. (2013). Gifts, Loans and Intergenerational Support for Young Adults. Sociology, 47(6): 1120-1135. https://doi. org $/ 10.1177 / 0038038512455736$

Hugo, G. J., Hull, T. H., Hull, V. J., \& Jones, G.W. (1987). The demographic dimension in Indonesian development. Oxford : Oxford University Press

Jansen, S, Coolen, H. \& Goetgeluk, R. (2011). The Measurement and Analysis of Housing Preference and Choice. Dordrecht: Springer Netherlands

Jabareen, Y. (2005). Culture and Housing Preferences in a Developing City. Environment and Behavior, 37(1): $\quad$ 134-146. https://doi. org/10.1177/0013916504267640

Mackie, P. K. (2016). Young people and housing: identifying the key issues, International Journal of Housing Policy, 16(2): 137-143. https://doi.org/10.1080/14616718.2016.11 59273

Mulder, C. H. (2013). Family dynamics and housing: Conceptual issues and empirical findings. Demographic Research, 29: 355378. Retrieved April 7, 2019, from http:// www.jstor.org/stable/26348158

Mulder, C.H., \& Lauster, N. T. (2010). Housing and Family: An Introduction. Housing Studies, 25(4): 433-440. https://doi. org/10.1080/02673031003771109

Myers, D., Painter, G., Yu, Z., Ryu, S.H., \& Wei, L. (2005) Regional disparities in homeownership trajectories: Impacts of affordability, new construction, and immigration, Housing Policy Debate, 16(1): 53-83. https://doi.org/10.1080/10511482.2 005.9521534

Smits, J., Mulder, C.H., \& Hooimeijer, P. (2007). Migration of couples with non employed and employed wives in the Netherlands: the changing effects of the partners' characteristics. Journal of Ethnic and Migration Studies, 30(2): 283- 301. https:// doi.org/10.1080/1369183042000200704

Mulyano, Y., Rahadi, R., \& Amaliah, U. (2020). 
Millennials Housing Preferences Model in Jakarta. European Journal of Business and Management Research, 5(1). https://doi. org/10.24018/ejbmr.2020.5.1.240

Priemus, H. (1984). Verhuistheorieën en de verdeling van de woningvoorraad. Delft: Delft University Press.

Rapoport, A. (2000). Theory, Culture and Housing. Housing, Theory, and Society, 17(4): 145-165. doi:10.1080/1403609003 00108573

Reid, A. (2011). Menuju Sejarah Sumatra: Antara Indonesia dan Dunia. Jakarta: Yayasan Pustaka Obor Indonesia

Salazar, N. (2016). The (Im)Mobility of Merantau as a Sociocultural Practice in Indonesia. In Bon N. \& Repič J. (Eds.), Moving Places: Relations, Return and Belonging. 2142. New York, Oxford: Berghahn Books. https://doi.org/10.2307/j.ctvr694z4.4

Simanjuntak, B. A. (2009). Konflik Status dan Kekuasaan Orang Batak Toba: Bagian Sejarah Batak. Jakarta: Yayasan Pustaka Obor Indonesia. Retrieved April 7, 2019, from https://books.google.co.id/books?id= rintsec=frontcover $\# v=$ onepage \&q\&f=false

Sjørslev, I. (2012). "Cash the Equity and Realize Yourself": An Anthropological Approach to House Values. Housing, Theory and Society, 29(4): 382-400. https://doi.org/10 $.1080 / 14036096.2012 .655381$

Tan, T. H. (2012). Meeting first-time buyers' housing needs and preferences in greater Kuala Lumpur. Cities, 29(6): 389-396. https://doi.org/10.1016/j.cities.2011.11.016

Vergouwen, J. C. (2004). Masyarakat dan Hukum Adat Batak Toba. Yogyakarta: Lkis Pelangi Aksara. Retrieved April 7, 2019, from https://books.google.co.id/s?id=ry9q DwAAQBAJ\&printsec $=$ frontcover\#v=onep age \&q\&f=false

Weiner, B. (1992). Human motivation: Metaphors, theories, and research. New York: Sage Publications, Inc.

$\mathrm{Yu}$, Z. (2021). Homeownership attainment of adult children in urban China: Parental attributes and financial support. Housing Studies, 36(6): 789-821. https://doi.org/10 .1080/02673037.2020.1720617

Zahirovic-Herbert, V., \& Gibler, K. M. (2019). "Neighbouring House Transaction Response to Assisted Living Facilities and Nursing Homes." Housing Studies, 35(2): 195-213. https://doi.org/10.1080/0267303 7.2019.1594714 